\title{
Gambaran Benigna Prostat Hiperplasia di RSUP Prof. Dr. R. D. Kandou Manado Periode Januari 2014 - Juli 2017
}

\author{
${ }^{1}$ Filzha Adelia \\ ${ }^{2}$ Alwin Monoarfa \\ ${ }^{2}$ Angelica Wagiu \\ ${ }^{1}$ Program Studi Pendidikan Dokter Fakultas Kedokteran Universitas Sam Ratulangi Manado \\ ${ }^{2}$ Bagian Bedah Fakultas Kedokteran Universitas Sam Ratulangi Manado \\ Email: filzhaadelia96@yahoo.com
}

\begin{abstract}
Benign prostatic hyperplasia (BPH) is defined as stromal cell proliferation of prostate gland which causes enlargement of the gland. It manifests as urine flow disturbance, difficult to urinate, and desire to urinate, however, the urine emission is low. In 2013, Indonesia has 9.2 million cases of BPH among men aged over 60 years. This study was aimed to obtain the profile of BPH cases at Prof. Dr. R. D. Kandou Hospital Manado in the period of January 2014 to June 2017. This was a retrospective descriptive study at Medical Record Installation of Prof. Dr. R. D. Kandou Hospital. The results showed that during that period of time, the highest percentage of cases was in 2016 (38.46\%) and the most common age group was 61-70 years old (46.15\%). The main complaint among the patients was difficult to urinate and the most frequently performed action was transurethral resection of prostate (TURP) (51.28\%). Conclusion: In this study, BPH cases were most common at the age group 61-70 years old. Moreover, TURP was the most common action performed.
\end{abstract}

Keywords: benign prostatic hyperplasia

\begin{abstract}
Abstrak: Benigna prostat hiperplasia (BPH) didefinisikan sebagai proliferasi dari sel stromal pada prostat, yang menyebabkan pembesaran kelenjar tersebut. Manifestasi BPH dapat berupa terganggunya aliran urin, sulit buang air kecil (BAK), dan keinginan buang air kecil namun pancaran urin lemah. Pada tahun 2013 di Indonesia terdapat 9,2juta kasus BPH, umumnya diderita laki-laki berusia di atas 60 tahun. Penelitian ini bertujuan untuk mendapatkan gambaran kasus BPH di RSUP Prof. Dr. R. D. Kandou Manado periode Januari 2014 - Juli 2017. Jenis penelitian ialah deskriptif retrospektif, yang dilakukan di Instalasi Rekam Medik RSUP Prof. Dr. R. D. Kandou Manado. Hasil penelitian menunjukkan bahwa jumlah kasus BPH tertinggi pada tahun $2016(38,46 \%)$ dan pada kelompok usia 61-70 tahun (46,15\%). Keluhan utama semua pasien ialah sulit BAK. Tindakan yang paling sering digunakan yaitu transurethral resection of prostate (TURP) (51,28\%). Simpulan: Kasus BPH terutama ditemukan berusia 61-70 tahun. Tindakan yang paling sering dilakukan yaitu reseksi prostat transuretra (TURP).
\end{abstract}

Kata kunci: benigna prostat hiperplasia

Prostat terletak antara tulang kemaluan dan dubur, mengelilingi saluran uretra pada pintu saluran yang masuk ke kandung kemih. Ketika urin keluar dari kandung kemih, akan melewati saluran di dalam kelenjar prostat, yang disebut uretra prostat. ${ }^{1}$ Benigna prostat hiperplasia (BPH) merupakan penyakit tersering kedua di klinik urologi di Indonesia setelah batu saluran kemih. ${ }^{2}$ Prevalensi histologi BPH meningkat dari $20 \%$ pada lakilaki berusia $41-50$ tahun, $50 \%$ pada laki-laki usia 51-60 tahun hingga lebih dari 90\% pada laki-laki berusia di atas 80 tahun $^{3}$

Gejala pertama kali dapat muncul pada usia kurang lebih 30 tahun. Manifestasinya dapat berupa terganggunya aliran urin, sulit 
buang air kecil dan keinginan buang air kecil (BAK) namun pancaran urin lemah. ${ }^{4}$

Menurut data WHO (2013), diperkirakan terdapat sekitar 70 juta kasus degeneratif, salah satunya ialah BPH, dengan insidensi di negara maju sebanyak 19\%, sedangkan di negara berkembang sebanyak $5.35 \%$ kasus. Tahun 2013 di Indonesia terdapat 9,2 juta kasus $\mathrm{BPH}$, di antaranya diderita oleh lakilaki berusia di atas 60 tahun. ${ }^{5}$

Penanganan BPH dapat dilakukan dengan berbagai cara antara lain watch full waiting, medikamentosa, dan tindakan pembedahan. Transurethral resection prostate (TURP) menjadi salah satu tindakan pembedahan yang paling umum dilakukan untuk mengatasi pembesaran prostat. ${ }^{6}$

\section{METODE PENELITIAN}

Jenis penelitian ini ialah deskriptif retrospektif. Penelitian dilakukan di Instalasi Rekam Medik RSUP Prof. Dr. R. D. Kandou Manado menggunakan data sekunder berupa catatan rekam medik pasien dengan BPH periode Januari 2014 - Juli 2017. Pengolahan data dilakukan secara manual menggunakan komputer.

\section{HASIL PENELITIAN}

Dari hasil penelitian yang dilakukan di Instalasi Rekam Medik RSUP Prof. Dr. R. D. Kandou Manado selama periode Januari 2014-Juli 2017, didapatkan 61 pasien dengan diagnosis utama BPH namun data pasien yang tersedia dan lengkap hanya 39 kasus. Jumlah kasus tertinggi yaitu pada tahun 2016 dengan 15 pasien $(38,46 \%)$ dan terendah pada tahun 2015 dengan 3 pasien $(7,69 \%)$.

Tabel 1. Distribusi pasien BPH berdasarkan jumlah kasus per tahun

\begin{tabular}{ccc}
\hline Tahun & Jumlah & Persentase \\
\hline 2014 & 11 & $28,21 \%$ \\
2015 & 3 & $7,69 \%$ \\
2016 & 15 & $38,46 \%$ \\
2017 & 10 & $25,64 \%$ \\
Total & 39 & $100 \%$ \\
\hline
\end{tabular}

Dari hasil penelitian didapatkan kasus $\mathrm{BPH}$ terbanyak pada kelompok usia 61-70 tahun yaitu 18 pasien $(46,15 \%)$, sedangkan pada kelompok usia 41-50 tahun paling sedikit ditemukan pasien BPH, yaitu 2 pasien $(5,13 \%)$.

Tabel 2. Distribusi pasien BPH berdasarkan usia pasien

\begin{tabular}{ccc}
\hline $\begin{array}{c}\text { Kelompok } \\
\text { usia }\end{array}$ & Jumlah & Persentase \\
\hline $41-50$ & 2 & $5,13 \%$ \\
$51-60$ & 6 & $15,38 \%$ \\
$61-70$ & 18 & $46,15 \%$ \\
$71-80$ & 10 & $25,64 \%$ \\
$>80$ & 3 & $7,69 \%$ \\
Total & 39 & $100 \%$ \\
\hline
\end{tabular}

Dari 39 pasien dengan BPH didapatkan seluruh pasien datang dengan keluhan utama sulit buang air kecil.

Tabel 3. Distribusi pasien BPH berdasarkan keluhan utama

\begin{tabular}{ccc}
\hline $\begin{array}{c}\text { Keluhan } \\
\text { utama }\end{array}$ & Jumlah & Persentase \\
\hline $\begin{array}{c}\text { Sulit BAK } \\
\text { Total }\end{array}$ & 39 & $100 \%$ \\
\hline
\end{tabular}

Dari hasil penelitian didapatkan bahwa tindakan terbanyak pada pasien BPH yaitu TURP dengan 20 pasien $(51,28 \%)$ dan terendah dengan open prostatectomy yaitu 5 pasien $(12,82)$.

Tabel 4. Distribusi pasien BPH berdasarkan tindakan

\begin{tabular}{ccc}
\hline Tindakan & Jumlah & Persentase \\
\hline TURP & 20 & $51.28 \%$ \\
Medikamentosa & 14 & $35.90 \%$ \\
Open prostatectomy & 5 & $12.82 \%$ \\
Total & 39 & $100 \%$ \\
\hline
\end{tabular}

\section{BAHASAN}

Dari hasil penelitian di RSUP Prof. Dr. R. D. Kandou Manado dalam kurun waktu 3 tahun, yaitu dari tahun 2014 - 2017, ditemukan sebanyak 39 kasus yang memenuhi kriteria inklusi di Bagian Rekam Medik. 
Berdasarkan Tabel 1 didapatkan bahwa pasien BPH terbanyak pada tahun 2016 yaitu 15 pasien $(38,46 \%)$, disusul tahun 2014 sebanyak 11 pasien $(28,21 \%)$, dan tahun 2017 sebanyak 10 pasien $(25,64 \%)$, dan yang paling sedikit tahun 2015 sebanyak 3 pasien (7,69\%). Hasil ini menunjukkan bahwa tahun 2016 dengan angka kejadian BPH tertinggi.

Berdasarkan Tabel 2 didapakan bahwa pasien BPH dengan jumlah tertinggi pada kelompok usia 61-70 tahun 18 pasien $(46,15 \%)$. Sekitar 5 juta laki-laki di Indonesia berusia 60 tahun menderita gejala saluran kemih bagian bawah akibat BPH. Gejala awal BPH meningkat 50\% pada usia 60 tahun dan akan sangat tinggi $90 \%$ pada usia $>80$ tahun. $^{7}$

Berdasarkan Tabel 3 didapatkan bahwa keluhan utama saat pasien masuk rumah sakit, kesemuanya datang dengan keluhan sulit BAK. Gejala BPH sangat bervariasi yang diakibatkan obstruksi uretra dan menyebabkan hilangnya fungsi kemih secara bertahap, namun gejala yang paling umum mengakibatkan masalah ialah sulit BAKl. ${ }^{8}$

Berdasarkan Tabel 4 didapatkan bahwa tindakan yang paling sering dilakukan pada pasien BPH yaitu TURP sebanyak 20 pasien $(51,28 \%)$, diikuti pengobatan medikamentosa sebanyak 14 pasien $(35,90 \%)$. TURP menjadi salah satu tindakan pembedahan yang paling umum dilakukan untuk mengatasi pembesaran prostat. Tindakan pembedahan ini dipilih karena memiliki efek minimal jika dibanding- kan dengan jenis pembedahan lainnya. Selain tindakan operatif juga digunakan pengobatan medikamentosa dengan obat-obatan pengham-bat adrenergik$\alpha$ (adrenergic $\alpha$-blocker) dan mengurangi volume prostat sebagai komponen statik dengan cara menurunkan kadar hormon testosteron/dihidrotestosteron melalui penghambat $5 \alpha$-reduktase. ${ }^{6}$

\section{SIMPULAN}

Berdasarkan hasil penelitian di Instalasi Rekam Medik RSUP Prof. Dr. R. D. Kandou Manado dalam periode Januari 2014- Juli 2017, dapat disimpulkan bahwa angka kejadian benigna prostat hiperplasia selama periode Januari 2014- Juli 2017 yang tertinggi pada tahun 2016 dan paling rendah pada tahun 2015. Kelompok usia yang terbanyak menderita BPH ialah 61-70 tahun. Sulit BAK merupakan keluhan yang dialami seluruh pasien, dan tindakan yang tersering dilakukan yaitu TURP.

\section{SARAN}

Disarankan agar data pasien di Instalasi Rekam Medik disimpan dan ditata secara baik agar memudahkan dalam melakukan pencarian jika sewaktu-waktu dibutuhkan.

Disarankam pada laki-laki usia lanjut dengan gangguan buang air kecil agar segera memerik-sakan diri kedokter spesialis urologi.

\section{DAFTAR PUSTAKA}

1. Arif, Mansjoer, et al. Kapita Selekta Kedokteran (4th ed). Jakarta: Medica Aesculapius FKUI, 2014.

2. Fadlol, Mochtar. Prediksi volume prostat pada penderita pembesaran prostat jinak. Indonesian Journal of Surgery. 2013; XXXIII-4:139-45.

3. Cooperberg MR, Birkmeyer JD, Litwin MS. Defining high quality health care. Urologic Oncology: Seminars and Original Investigations. 2013; 27(4):4116.

4. Kapoor A. Benign prostatic hyperplasia (BPH) management in the primary care setting. The Can J Urol. 2012;194:10-5.

5. Riset Kesehatan Dasar (Riskesdas). (2013). Badan Penelitian dan Pengembangan Kesehatan Kementerian RI tahun 2013. [cited 2017 Sept 13]. Available from: http://www.depkes.go.id/resources/downl oad/general/Hasil\%20Riskesdas\%20 2013.pdf

6. Purnomo BB. 2012. Buku Kuliah DasarDasar Urologi. Jakarta: Infomedika, 2012; p. 93.

7. Benign Prostatic Hyperplasia. Astellas. Available online: http:/www.astellas. us/t_areas/ urology.php

8. Prevalence and impact of BPH. Available online: http://www.4flomax.com/HCP/bphbasics/prevalence.jsp. 